\title{
An experimental investigation of the influence of the formation of a plastic hinge on the shear strength of a singly reinforced concrete beam*
}

\author{
by N. M. Khan, M.Sc.(Eng.), D.I.C. and A. H. Mattock, M.Sc.(Eng.), Ph.D., D.I.C.
}

\section{Contribution by J. D. Bennett \\ (Twisteel Reinforcement Ltd)}

At first sight, the authors appear to have shown that the shear strength of a plastic hinge is greater than that of an uncracked section. This result is contrary to that obtained by other investigators ${ }^{(1-3)}$ and does not appear reasonable.

On closer examination, it is obvious that Test No. 2 is not a test of the shear strength of an uncracked section. This test was carried out on a beam of $2 \mathrm{ft}$ span with a central point load, and these conditions give a bending moment at the centre of the beam which is numerically equal to the shear force. Thus the last column of Table 2 also gives the bending moment in tons $\mathrm{ft}$ at failure in Test 2. A comparison of these moments with the plastic hinge moments shows that, in the majority of cases, the plastic hinge moment was either reached or exceeded before failure occurred. This means that Test 2 was merely a repetition of Test 1 , and a reason for the lower failure loads must be found elsewhere.

The authors state in their paper that the second series of tests was carried out on an undamaged section of the beam from Test 1 . Thus the reinforcement in Test 2 would have no hooks at one end, and failure could have been due to bond slip. The possibility of a local bond failure should not be overlooked, as the local bond stress at failure in all the tests was between 320 and $580 \mathrm{lb} / \mathrm{in}^{2}$, assuming a lever arm of 7 in.

It has often been shown that the longitudinal reinforcement contributes a certain proportion to the shear strength of a beam. If the maximum stress in the reinforcement has been reached due to bending, then it seems logical to assume that it can no longer take any additional forces which would add to the shear strength of the beam and so the shear strength of a plastic hinge should be less than that of an uncracked section. It would therefore be dangerous to accept the authors' conclusion as a basis for practical design.

*Pages 151-156

\section{Reply by the authors}

The three references ${ }^{(1-3)}$ mentioned by Mr Bennett do not in fact contain any experimental results which are comparable with those obtained in the tests described. As a result of the occurrence of shear failures in three of his tests on continuous beams, Dr Hajnal-Kónyi " " rightly draws attention to the need to ensure adequate shear strength if complete redistribution of bending moments is to be obtained before failure in flexure of a continuous reinforced concrete beam. The three shear failures described in reference (1) are not comparable with those obtained by the authors, since they occurred before formation of a plastic hinge at the support, and were principally attributable to the low strength of concrete used.

Sahlin and Nylander ${ }^{(2,3)}$ deduce, from the observation that the internal lever arms of heavily reinforced sections reduce as the sections reach their ultimate moment, that the shear strength of a support section of a continuous beam will be reduced as the section approaches its ultimate moment. This conclusion may be true for sections in which flexural failure is due to crushing of the concrete whilst the steel strain is still elastic, resulting in a low level of neutral axis and consequent short lever arm. However, in the tests reported by the authors, all the sections were under-reinforced, which resulted in a high levei of neutral axis at failure with, if anything, an increase in the lever arm as compared with the "straight line" calculation for working load.

The bending moments at failure in Tests 2 were indeed almo equal to, or slightly in excess of, the moments at which a plastic hinge started to form in Tests 1 (due to commencement of steel yield), for corresponding beams. However, in no case did the main reinforcement yield during Tests 2, fine flexure cracks only being observed and these not penetrating far above the level of the steel. This was probably because the lever arm at shear failure in Tests 2 was greater than the lever arm at first yield of the steel in Tests 1 . In Tests 2 the neutral axis at failure was seen to be higher than when the steel yield occurred in Tests 1 . 
The failures in Tests 2 were all by shearing through the compression zone; the diagonal tension cracks remained fine at the level of the steel up to failure, indicating that bond slip had not occurred. Failure occurred in all cases in the shear span having hook anchorage to the reinforcement. These failures were in no way similar to bond failures witnessed by the authors during the course of another investigation carried out at Imperial College.

With reference to the last paragraph of Mr Bennett's contribution, Morrow and Viest ${ }^{(4)}$ at the University of Illinois have reported that, under certain conditions and for short shear spans, shear failures can occur after yielding of the reinforcement, at a bending moment in excess of that at which a pure flexural failure should have occurred.

The authors would like to emphasize the need for more research work to be undertaken on the subject of the shear strength of reinforced concrete beams. The tests described in the original article were of an ad hoc nature, designed to compare the shear strengths of a strictly limited range of sections. The conclusions drawn, therefore, should be applied only to beams with a similar degree of reinforcement, and for short shear spans.

\section{REFERENCES}

1. HAJNAL-KóNYI, K. and LeWIS, H. E. Moment redistribution in continuous beams reinforced with plain and deformed bars. Proceedings of the Symposium on the Strength of Concrete Structures, London, May 1956. Session B. Paper 4. (In press.)

2. SAHLIN, S. Effekt av långtgående betongstukning vid betongbalk påverkad av böjande moment. (The effect of far-advanced compressive strains of concrete in reinforced concrete beams submitted to bending moments.) Betong. Vol. 40, No. 2. 1955. pp. 135-149. C \& C A Library Translation No. 66.

3. NYLANDER, H. and SAHLIN, S. Undersökning av Kontinuerliga betongbalkar vid långtgående betongstukning. (Investigation of continuous concrete beams at far-advanced compressive strains in the concrete.) Betong. Vol. 40, No. 3. 1955. pp. 241-275. C \& C A Library Translation No. 67.

4. MORROW, J. and VIEST, I. M. Shear strength of reinforced concrete frame members without web reinforcement. Journal of the American Concrete Institute. Vol. 28, No. 9. March 1957. pp. 833-869. 